\title{
UN ESPACIO FUNERARIO OLVIDADO: LA CAPILLA DE LOS FAJARDO EN SANTA MARÍA LA MAYOR DE BAENA (CÓRDOBA) ${ }^{1}$
}

\section{JESUS SUÁREZ ARÉVALO \\ UNED}

RESUMEN: En este trabajo presentamos una aproximación a la capilla funeraria que Pedro Luis de Valenzuela Fajardo y Monte, caballero de Santiago y veinticuatro de Córdoba, mandó erigir a finales del siglo XVII en la parroquia de Santa María la Mayor de Baena. Se trata de un espacio barroco poco estudiado hasta ahora y en cuya génesis intervinieron José Granados de la Barrera y Melchor de Aguirre, maestros mayores de la catedral de Granada.

PALABRAS CLAVE: Capilla funeraria, mecenazgo artístico, maestro mayor de la catedral de Granada, Baena (Córdoba), José Granados, Melchor Aguirre.

\section{A FORGOTTEN BURIAL SITE: THE FAJARDO CHAPEL IN SANTA MARÍA LA MAYOR IN BAENA (CORDOBA)}

\begin{abstract}
The objective of this work is to make an approach to the works undertaken at the end of the 17th century in his family chapel in the parish church of Santa María la Mayor of Baena (Cordoba) by Pedro Luis de Valenzuela Fajardo y Monte, knight of Santiago and Municipal Councillor in Córdoba. It is a forgotten baroque burial site. It is a work of Joseph Granados de la Barrera and Melchor de Aguirre, both master builders of the cathedral of Granada.
\end{abstract}

KEYWORDS: Funerary chapel, Artistic patronaje, Granada cathedral master builder, Baena (Cordoba), Jose Granados, Melchor Aguirre.

\footnotetext{
${ }^{1}$ Este trabajo se inscribe en el proyecto de tesis doctoral Aproximación a la ciudad nobiliaria de los reinos de Córdoba y Sevilla en la edad moderna como tipología urbana, dentro del programa de Doctorado de Historia, Historia del Arte y Territorio de la UNED.
} 


\section{El comitente: Pedro Luis de Valenzuela Fajardo y Monte}

Pedro Luis de Valenzuela Fajardo pertenecía a una rama lateral del linaje de los Valenzuela, una de las familias nobles más antiguas de Baena, señores de la villa de Valenzuela y alcaides hereditarios del castillo de Baena. Ésta surgió en el siglo XVI cuando el militar, Pedro Fernández de Valenzuela casó con Isabel de Fajardo Mendoza, natural de Málaga.

Sus padres, Luis de Valenzuela Fajardo e Isabel Monte y Mendoza², ambos vecinos y naturales de Baena, tuvieron ocho hijos ${ }^{3}$. En 1650 el padre fue nombrado gobernador de Popayán (Colombia $)^{4}$. Era la culminación de una larga carrera en el ejército y la administración ${ }^{5}$. Lo acompañaron sus hijos Pedro Luis, Diego, Antonio, Juan y Francisco, quedando en tierra la madre, enferma, y las hijas, Isabel ${ }^{6}$, Francisca Antonia y Elvira ${ }^{7}$. La madre y las hijas se establecieron en Córdoba mientras los varones de la familia estaban en América ${ }^{8}$. En la licencia para viajar a Indias, Pedro Luis, que ya era familiar del Santo Oficio en Córdoba (1642) y caballero de Santiago (1649) ${ }^{9}$, fue descrito por los funcionarios de la Casa de la Contratación como un individuo de 21 años «de cabello crespo y rubio, que le apunta la

\footnotetext{
2 Sirvió durante más de dieciocho años en el ejército, en África, Italia, y la Carrera de Indias. A partir de 1643 ocupó diversos cargos en la administración, primero como gobernador de Villanueva de la Serena (1643) y poco después corregidor de Guadix, Baza y Almería, puesto que desempeñó hasta poco antes de ser nombrado gobernador de Popayán (Colombia). Cfr.: Relación de Méritos y servicios de Luis de Valenzuela Fajardo, caballero de la Orden de Alcántara, Archivo General de Indias, INDIFERENTE,113, N.57, 23-10-1647, sin foliar. La madre, aunque natural de Baena, tenía por parte de padre, Francisco Monte de la Isla, ascendientes originarios de Alcalá la Real, localidad con la que por entonces están muy relacionados los de Baena. HORCAS GÁLVEZ, Manuel: «Historia y linajes en Santa María la Mayor de Baena», en Patrimonio y turismo: una vía para el desarrollo económico, Baena, Cursos de verano de la Universidad de Córdoba en Baena «Cordvba 2011». Inédito, p. 22.

3 Pruebas para la concesión del Título de Caballero de la Orden de Santiago de Luis de Valenzuela Fajardo y Monte, natural de Baena, Familiar del Santo Oficio de Córdoba, 1649, Archivo Histórico Nacional (AHN), OM-CABALLEROS SANTIAGO, Exp. 8468, f. 1r.

${ }^{4}$ Nombramiento de Luis de Valenzuela Fajardo como Gobernador de Popayán, 1648-7-25 Madrid, Archivo General de Indias (AGI), CONTRATACION, 5794, L. 1, 25-7-1648, ff. 44v-48v.

${ }^{5}$ Relación de Méritos..., op. cit., AGI, INDIFERENTE,113, N.57, 23-10-1647, sin foliar.

${ }^{6}$ La hermana mejor documentada es Isabel Valenzuela y Fajardo. Nacida en Baena el 6-12-1634 casó con Luis Antonio Togores y Rosell, señor de la Jacarilla, en 1663, trasladando su residencia a Orihuela. Cfr.: DE LA GUARDIA SALVETTI, Rafael: Nobiliario alicantino, Alicante, Diputación Provincial de Alicante, 1983, p. 330; GÁLVEZ FERRÁNDEZ, Manuel: Los Togores señores de Jacarilla, siglos XV-XIX, Alicante, Ayuntamiento de Jacarilla, 2015, pp. 222-224. También Tabla genealógica de la familia de Valenzuela, vecina de Córdoba. Real Academia de la Historia (RAH), 9/310, f. 110.

${ }^{7}$ Cfr.: RAMOS MAMPASO, Antonio: Descripción genealógica de la Casa de Aguayo, Málaga, Imprenta de la Dignidad Episcopal, 1781, p. 495. Sólo aparecen mencionados las tres hermanas y los dos hermanos mayores.

8 Poderpara administrar conferido por el capitán don Pedro Luis de Valenzuela Fajardo a las señoras D Isabel Monte y Mendoza, su madre, y $D^{a}$ Francisca, $D^{a}$ Isabel y $D^{a}$ Elvira de Valenzuela Fajardo sus hermanas... [....], Archivo Histórico de Viana (AHV), Fondo Viana, Administración y Cuentas, Caja L0407, Expediente E0151, 25-09-1654, f. 1 r.

${ }^{9}$ AHN, OM-CABALLEROS_SANTIAGO, Exp. 8468, Pruebas... op. cit., f. 1 r.
} 
barba, de buen cuerpo» ${ }^{10}$. Por lo poco que sabemos de su estancia en la actual Colombia, parece que llevó una vida turbulenta. En 1654 viaja a Santa Fé de Bogotá con el rango de capitán para llevar a cabo una misión que le encomendó su padre. Allí fue acusado de conducta escandalosa y discutió con un oidor de la Audiencia ${ }^{11}$.

Se desconoce el momento exacto de su regreso a España y de su matrimonio con su prima, Anastasia de Valenzuela Mendoza y Zayas. En 1665 está documentado su regreso a Baena y la persistencia de sus problemas con la justicia derivados de los incidentes de ocurridos en Bogotá once años atrás ${ }^{12}$. Dos años más tarde, en enero de 1667, está en Córdoba, donde obtiene un oficio de caballero veinticuatro en el cabildo municipal ${ }^{13}$. Tras la muerte de su esposa en 1679 y su renuncia a su puesto en el cabildo municipal ${ }^{14}$, se ordena sacerdote en fecha desconocida ${ }^{15}$. Falleció en una casa de la collación de Santa Marina, el 1 de marzo de $1689^{16}$. Mientras se terminaban las obras de su panteón en Baena, pidió que su cuerpo «sea depositado en la capilla del Señor San Pablo» en la catedral de Córdoba ${ }^{17}$.

\footnotetext{
${ }^{10}$ Se trata de una descripción fechada el 31 de marzo de 1650 de los cinco hijos varones de Luis de Valenzuela que lo acompañan a Colombia. AGI, CONTRATACION, 5429, N. 8, Expediente de información y licencia de pasajero a Indias de Luis Valenzuela Fajardo, 8-4-1650, f. 2r. Esta descripción ya fue publicada por Antonio Moreno Hurtado, cfr:: MORENO HURTADO, Antonio: Egabrenses en Indias, Cabra, Ayuntamiento de Cabra, 2010, p. 224.

${ }^{11} \mathrm{La}$ intercesión paterna no pudo evitar que la Audiencia de Santa Fé lo condenara a cuatro meses de cárcel, al pago de una multa de 2.000 pesos y al destierro de Santa Fé. 1661, Pedro Luis Valenzuela Fajardo, Gobernador de Popayán, con el fiscal sobre restitución de una multa. Fenecido en 1667. 3 piezas. AGI. PLEITOS AUDIENCIA DE SANTA FE, ESCRIBANIA, 770B, ff. 4r y 20r-21r. En este aspecto fue digno hijo de su padre, ya que Luis Valenzuela tuvo varios problemas con la Audiencia por excederse en sus atribuciones y con la Inquisición, que lo procesó e incluso llegó a excomulgarlo, por haber apaleado personalmente en la ciudad de Pasto a uno o dos clérigos y jactarse públicamente de ello, faltando el respeto a los distintos santos. Cfr:: MORENO HURTADO, Antonio: Egabrenses en Indias, op. cit., pp. 264-268.

${ }^{12}$ Ibidem, f. 22 r.

${ }^{13}$ Obtuvo el cargo por resignación de Pedro de Heredia y Córdoba. Expediente instruido en virtud de Real Cedula para probar si en Pedro Luis de Valenzuela Fajardo concurrian las calidades requeridas para ser Caballero Veinticuatro de Cordoba, Archivo Municipal de Córdoba (AHMCO), Expedientes de pruebas de nobleza, SF/C 00026-267, 1667, f. 3 r.

${ }^{14} \mathrm{La}$ fecha de su renuncia no está del todo clara. Aunque en el expediente de su sucesor, su primo Gómez Fernández de Córdoba y Figueroa, se dice que resignó su puesto en febrero de 1679, en su testamento, fechado 10 años más tarde, sigue utilizando el título, y los trámites oficiales para que Gómez Fernández de Córdoba ocupara el cargo no comenzaron hasta un año más tarde, en septiembre de 1690. Expediente instruido en virtud de Real Cédula para probar si en Gómez. Fernández de Córdoba y Figueroa concurrian las calidades requeridas para ser Caballero Veinticuatro de Córdoba. Refrenda Manuel Fernández de Cañete, escribano mayor de Cabildo. Doc. 310, SF/C 00026-310, 13-09-1690, sin foliar.

${ }^{15}$ El día 26 de febrero Francisco de Zehejin y Godinez, racionero entero de la catedral, provisor y vicario general del obispado de Córdoba, declara en un auto que «se le a dado notizicia como Pedro Luis Valenzuela Fajardo, caballero de la orden de Santiago, clérigo capellán vezino desta ciudad está muy agravado de enfermedad y a peligro de su vida y que por su testamento deja e instituie su alma por heredera». Por ese motivo, procede a nombrar una comisión para que haga inventario de sus bienes y hacienda en cuanto fallezca. Inventario, Aprecio y Almoneda de los bienes de Pedro Luis de Valenzuela, AHV, Fondo Viana, Sección Testamentarías, Caja C0106, Expediente E0021a, 16-03-1689, f. 25r.

${ }^{16}$ Archivo Histórico Provincial de Córdoba (AHPCO), Testamento de Pedro Luis Valenzuela Fajardo ante el escribano de Córdoba Juan Láinez de Calatrava, 9498P, 23-2-1689, f. 96r.

${ }^{17}$ Ibidem, f. 101v.
} 


\section{La fundación de la capilla}

El lugar elegido para su reposo definitivo era la capilla de San Jorge de la parroquia de Santa María la Mayor de Baena (imágenes 1 y 2), cuyo patronato había heredado de la familia Isla a través de su madre ${ }^{18}$, y a la que cambió de advocación por razones devocionales, llamándola a partir de entonces Nuestra Señora del Oratorio ${ }^{19}$. Este cambio se produce en el contexto de exaltado fervor mariano que se vivía en la España del siglo XVII y que cristalizó en la aparición de nuevas advocaciones, la revitalización de las antiguas, y sobre todo en la defensa a ultranza del dogma de la Inmaculada Concepción ${ }^{20}$. Pese a este cambio, siguió siendo conocida habitualmente hasta su destrucción como capilla de los Fajardo en recuerdo a la familia que ostentaba su patronato, y así aparece denominada en las descripciones del siglo XIX y principios del XX.

\section{Imágenes 1 y 2}

\section{Santa María la Mayor de Baena}
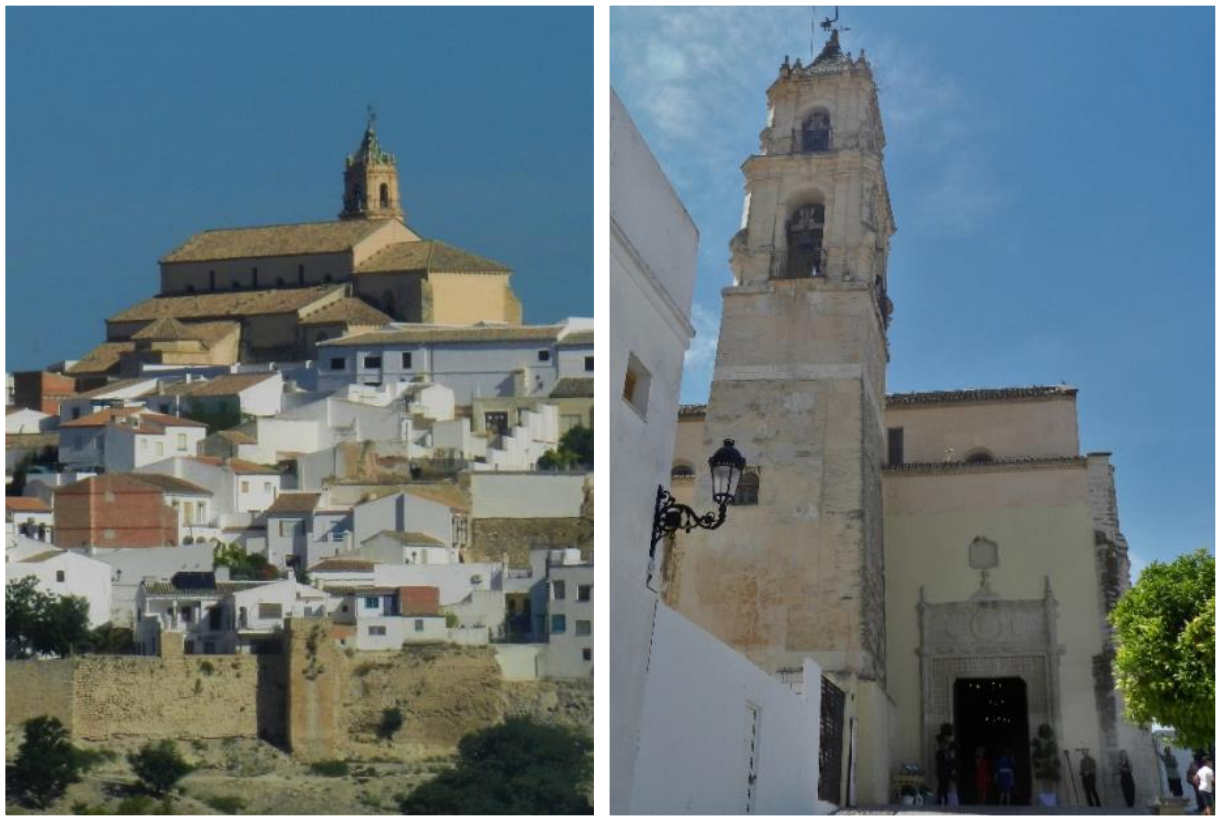

Fuente: Elaboración propia

\footnotetext{
${ }^{18}$ HORCAS GÁLVEZ, Manuel: «Historia y linajes...», op. cit., p. 22. Agradezco al autor su amabilidad al facilitarme copia de este interesante trabajo.

${ }^{19}$ AHPCO, Fundación de Capellanías y fiestas ante el escribano de Córdoba Juan Láinez de Calatrava, 9498P, 23-2-1689, ff.. 89r-90r. En el documento fundacional se afirma que tanto el fundador como su difunta esposa eran muy devotos de la Virgen y de la Sagrada Familia, y que por ese motivo se establece la entrega de una serie de limosnas en días señalados relacionados con esas advocaciones.

${ }^{20}$ Cfr.: POMAR RODIL, Pablo Javier: «El fervor mariano y la versatilidad del retablo. Algunos ejemplos parroquiales de Jerez de la Frontera»., Trocadero, 31, (2019), pp. 83-101. Para el ámbito cordobés ESCRIBANO NIETO, María José: «La religiosidad popular cordobesa: las advocaciones de gloria. Pervivencia y desaparición de estas imágenes y sus lugares de culto», en Advocaciones marianas de gloria, XX Simposium del Instituto Escurialense de Investigaciones Históricas y Artísticas, San Lorenzo del Escorial, 2012, pp. 263-314.
} 
Estaba situada entre la sacristía mayor del templo y la capilla del Subterráneo, perteneciente a otra rama de la familia Valenzuela (imagen 3, la capilla está rodeada por un círculo). No fue concebida como un panteón familiar, sino como un espacio funerario personal y exclusivo, en el que se unían su sepulcro y su devoción mariana ${ }^{21}$. Esta fórmula emulaba el ejemplo de varios prelados de la época como Trejo en Murcia, Sandoval en Toledo, y sobre todo al más cercano, el obispo de Córdoba, fray Alonso Salizanes ${ }^{22}$. Su capilla, erigida en la catedral de Córdoba entre 1679 y 1682 bajo la advocación de la Inmaculada, no solo proporcionó un modelo, también algunos de los artistas que trabajaron en ella intervendrían en la obra de Baena.

\section{Imagen 3}

\section{Planta de Santa María la Mayor de Baena con la ubicación y nombre de las capillas laterales existentes en 1639}

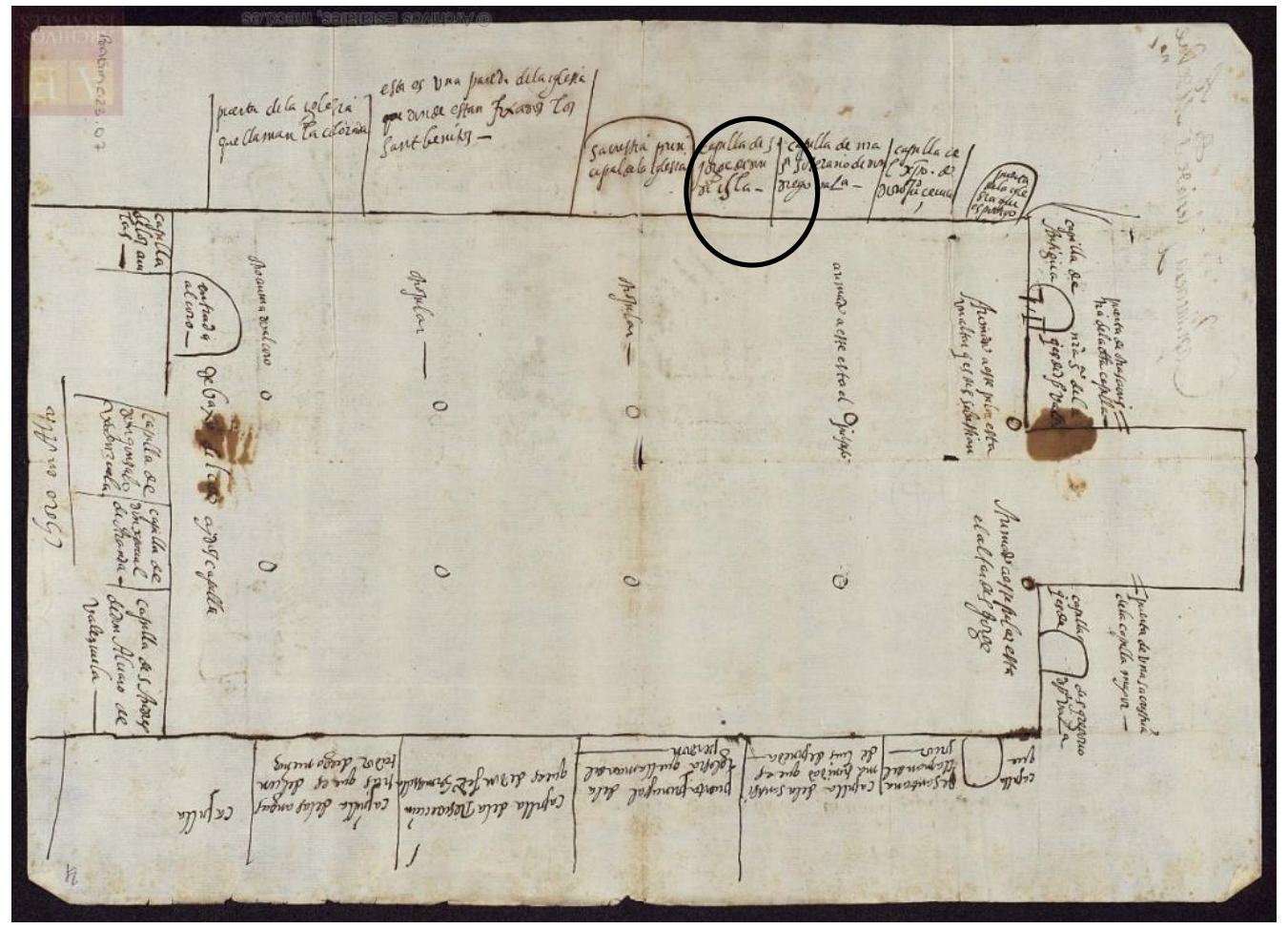

Fuente: Informes y planos de la planta de las obras realizadas en capilla mayor de la iglesia de Santa María [la Mayor] de Baena [para la sepultura de los condes de Cabra]. Archivo Histórico de la Nobleza (AHNOB), Baena, C.23, D.7-12, f. 4r.

\footnotetext{
21 «[...] mi deliberado ánimo es que en dicha capilla no se entierre persona alguna y solo esté en el hueco que ay en ella el cuerpo que fue de la dicha doña Anastasia de Valenzuela y Zayas, mi señora y mujer, y el mío quando Dios nuestro señor fuese serbido de llevarme. Hordeno y mando que los capellanes de dicha capilla no permitan de enterrarse a persona alguna de cualquier condizión o calidad aunque sean parientes enteros o patronos». AHPCO, Fundación de Capellanias..., op. cit., 23-2-1689, 9498P, f. 79r.

${ }^{22}$ RIVAS CARMONA, Jesús: «El arte franciscano en la Catedral de Córdoba: la Capilla Salizanes», en M. Peláez del Rosal (coord.), El arte franciscano en las catedrales andaluras, Córdoba, Caja Sur, 2005, pp. 151-152. En este artículo, Rivas Carmona revisa sus publicaciones anteriores sobre los mármoles en el barroco andaluz.
} 
A juzgar por la documentación notarial conservada, esta fundación debió de ser un objetivo prioritario durante sus últimos años de vida ${ }^{23}$. Con ello Pedro Luis de Valenzuela no hace sino reflejar los valores contrarreformistas que dominaban la sociedad española de la época. Tras haber vivido una juventud descarriada, durante su madurez muestra el perfil piadoso de una persona entregada a conseguir la salvación eterna, que en su testamento otorga numerosas limosnas y deja por heredera de sus bienes libres a su alma. Mediante una elevada inversión económica se construye un lugar de enterramiento exclusivo y digno de su estatus social. En ese sentido, la construcción de la capilla es un gasto ostentoso en signos o símbolos de prestigio necesarios para crear y mantener una imagen pública, lo que Thorstein Veblen llamó consumo ostentoso o «conspicuous consumption», y Pierre Bourdieu consideró inversiones en «capital simbólico» ${ }^{24}$. Sin embargo, con la inclusión de una obra pía y de tres capellanías también realiza una inversión en «bienes de salvación» ${ }^{25}$, que garantizan un flujo constante de limosnas, buenas obras, oraciones y misas por su alma, la de sus seres más allegados «y de aquellos a quienes debiere de justicia o charidad $\rangle^{26}$.

Puesto que no había tenido descendencia de su matrimonio con su prima, la citada Anastasia de Valenzuela Mendoza y Zayas, en su testamento declara que «sucede en mi casa y mayorazgo don Diego de Valenzuela, mi hermano que reside en Yndias ${ }^{27}$. En su ausencia, «en el ínterin que biene a España», dichos bienes serían administrados por su hermana Francisca Antonia, vecina de Orihuela y viuda ${ }^{28}$. Sin embargo, la gestión de la capilla y de la obra pía radicada en ella, regidas por el principio de agnación rigurosa que excluye a las

\footnotetext{
${ }^{23}$ «[...] mi deseo y deliberada voluntad siempre a sido de ynstituir y fundar una capilla y entierro con capellanes que la sirban y digan las misas y sufragios por mi alma y de la dicha doña Anastasia de Valenzuela y Zayas, mi amada y querida mujer que santa gloria aya». AHPCO, Fundación de Capellanías...op. cit., f. 75r.

${ }^{24}$ Cfr:: BURKE, Peter: «Conspicuous Consumption in Seventeenth-century Italy», en BURKE, Peter: The Historical Antbropology of Early Modern Italy: Essays on Perception and Communication, Cambridge (UK), Cambridge University Press, 2005, pp. 132-149.

${ }^{25}$ Cfr:: BOURDIEU, Pierre: «Génesis y estructura del campo religioso», Relaciones. Estudios de Historia y Sociedad [en línea], (2006), XXVII (108), pp. 29-83 Disponible en: https://www.redalyc.org/articulo.oa?id=13710803. [fecha de Consulta 29 de Agosto de 2020].

${ }^{26} \mathrm{Ibidem}$, f. 90v. Debido a su condición de eclesiástico en el momento de testar, estaba vinculado con la cofradía de San Pedro de Baena, que era la cofradía de los clérigos de la localidad. Por ello encarga a sus responsables que oficien dos misas de aniversario cada 29 de julio.

${ }^{27}$ Es el único hermano del que poseemos datos biográficos. Tras contraer matrimonio en 1661 con una de las herederas más ricas de Santafé de Bogotá, se estableció en esa ciudad donde siguió un brillante cursus honorum en la administración local, formando parte del patriciado urbano hasta su fallecimiento en 1733 . Uno de sus hijos, Agustín Blas, regresó a Córdoba, donde contrajo matrimonio y llegó a ser caballero veinticuatro del cabildo municipal. Cfr: VÁZQUEZ VARELA, Ainara y MARÍN LEOZ, Juana María: Señores del muy ilustre cabildo: Diccionario Biográfico del cabildo municipal de Santa Fe (1700-1810), Bogotá, Pontificia Universidad Javeriana, 2017, pp. 641-643.

${ }^{28}$ Había estado casada con Antonio Méndez, AHPCO, Codicilio de Pedro Luis Valenzuela Fajardo ante el escribano de Córdoba Juan Láinez de Calatrava, 9498P, 23-2-1689, f. 107r. Cfrr: RAMOS MAMPASO, Antonio: Descripción genealógica...,op. cit., p. 495, da los apellidos completos del difunto marido, Antonio de Asiaín y Agorateta Méndez de Sotomayor.
} 
mujeres $^{29}$, las deja en manos de sus albaceas testamentarios, a los que da poder para nombrar capellanes y supervisar todos los aspectos recogidos en la carta de fundación del patronato ${ }^{30}$.

Los trabajos tuvieron una duración muy prolongada, ya que empezaron en 1683 y fueron culminados por sus testamentarios en $1747^{31}$. El papel protagonista lo desempeñó su primo Fernando, de quien dice «fio de su christiandad y zelo [...] para que quede cumplido en todo» ${ }^{32}$.

Tanto la financiación de la construcción como su posterior mantenimiento dependían del cobro de las deudas contraídas por el duque de Sessa, «sesenta y un mill reales poco más o menos», y de los réditos del censo impuesto sobre Albendín (Córdoba), perteneciente a dicho duque de Sessa. Quizás esta sea una de las razones que expliquen la prolongación de la obra, y que el mismo fundador pida que «se fabrique dicha obra con la brevedad que sea posible» ${ }^{33}$.

\section{La traza de José Granados de la Barrera}

El 23 de febrero de 1683, Pedro Luis de Valenzuela Fajardo contrató en Baena con José Granados de la Barrera ${ }^{34}$, «maestro mayor de las obras de su excelencia el duque de Sesa y Baena, mi señor, y de las fábricas de la santa Yglesia de la ziudad de Granada», la

\footnotetext{
${ }^{29}$ «[...] excluyendo como desde luego excluyo perpetuamente a las hembras y barones de ellas a este patronato, porque mi voluntad es que lo sean únicamente los varones del dicho mi hermano, y faltando barones de barones desta línea, nombro por patrono a Don Fernando de Valenzuela Fajardo, mi primo hermano, vezino de la villa de Baena y sus hijoss». En caso de que las líneas sucesorias de los herederos de Fernando Valenzuela se extinguiesen, establece una lista compuesta por parientes más lejanos y, como último recurso, «fenecidas y acabadas todas las dichas líneas de varones según dicho es, suceda en el dicho patronato [...] los señores deán y cabildo de canónigos de la Santa Iglesia desta ciudad de Córdoba». Además de la propia capilla, el patronato comprendía tres capellanías perpetuas, y para ayudar a los tres capellanes, se dotaban un puesto de sacristán y un «ayuda terzerón» AHPCO, Fundación de Capellanias...op. cit., ff. 75r, 77v, 87v. y 92r.

${ }^{30}$ AHPCO, Codicilio...op. cit., ff. 107v-108r.

${ }^{31}$ RAMÍREZ DE LAS CASAS DEZA, Luis María: Corografía bistórico-estadística de la provincia y obispado de Córdoba, vol. 2, Córdoba, Monte de Piedad y Caja de Ahorros, 1986, p. 175.

32 AHPCO, Testamento..., op. cit., f. 100v.

33 AHPCO, Fundación de Capellanías...,op. cit., ff. 87v-88r.

${ }^{34} \mathrm{El}$ egabrense José Granados de la Barrera fue maestro mayor de las obras de la Catedral de Granada, entre 1667 y su fallecimiento en 1685, ya que, aunque desde enero de 1684 había sido cesado de empleo y sueldo por el Cabildo debido a sus ausencias reiteradas e injustificadas, el Arzobispo no había dado su visto bueno al cese. En la sesión del Cabildo catedralicio de 21 de mayo de 1683, se informaba que había faltado, sin permiso alguno, 4 meses y 18 días. GILA MEDINA, Lázaro: «La última etapa constructiva: de 1650 a 1704», en L. Gila Medina (coord.), El libro de la Catedral de Granada Tomo I, Granada, Cabildo Metropolitano de la Catedral de Granada, 2005, pp. 177. Con frecuencia justificó sus ausencias por la necesidad de llevar a cabo otros trabajos fuera de Granada ante la falta de ingresos que le producía la reiterada negativa del Cabildo a subirle el sueldo. Hasta ahora solo se conocían los trabajos que realizó para el III conde de Fernán Núñez en su villa homónima. ESPEJO JIMÉNEZ, Francisco Manuel: «Los molinos del maestro mayor de la catedral de Granada, José Granados de la Barrera, para la Casa de Fernán Núñez (Córdoba)», Ámbitos, 38 (2017), p. 78. Ahora debemos añadir este encargo en Baena que coincide cronológicamente con la ausencia sin permiso que hizo que el Cabildo lo suspendiera de empleo y sueldo.
} 
construcción de nueva planta de una capilla según las detalladas trazas que él mismo había delineado ${ }^{35}$.

Los términos del contrato por subasta o remate, escritos en «dos pliegos y medio de papel común» ${ }^{36}$, contemplaban que todos los gastos de materiales, portes, andamios y «manifacturas» corrían por cuenta de Granados «sin que para todo ello se le aya de dar mas que solo el dinero en que se conzerttan». Así mismo se compromete a costear la reparación de cualquier posible daño producido durante las obras ${ }^{37}$. Los trabajos se presupuestaron en ochenta y ocho mil reales de vellón con un plazo de ejecución de tres años contados desde primeros de marzo de 1683. El comitente se comprometía a pagar ochenta mil reales en 36 plazos mensuales. Los ocho mil restantes y otros dos mil más, en compensación por los costes, durante el año siguiente a la finalización de la obra. Este sistema de pagos, claramente ventajoso para el comitente, obligaba a Granados a actuar como un auténtico empresario que debía gastar una suma considerable para hacer frente a los gastos en materiales y personal de una obra de gran envergadura ${ }^{38}$.

En primer lugar, se debía demoler y desescombrar la capilla preexistente, y asegurarse de que la nueva cimentación no amenazase la estabilidad de la parroquia, «dejando las medianeras en la mesma forma que oy están» ${ }^{39}$. En el solar resultante, de planta rectangular (véase imagen 4, la hipotética planta de la capilla está rodeada por un círculo), se había de levantar una capilla de planta cuadrada y cubierta por una bóveda semiesférica sobre pechinas con tambor perforado por ventanas. Es el mismo sistema de iluminación utilizado en la capilla Salizanes, derivado del que se empleó en la catedral de Granada, y que tanto Granados

\footnotetext{
35 AHPCO, Postura y adjudicación de la fábrica de la capilla de Nuestra Señora del Oratorio ante el escribano de Baena Juan Muñoz Cardero, 366P, f. 293v. La documentación comienza el 16-10-1692 y termina el 21-03-1693. Hay un traslado de estas escrituras realizado por el mismo escribano baenense a petición del albacea, Fernando José de Valenzuela, el 8 de Aabril de 1698. Archivo de la Real Chancillería de Granada (ARChG), Probanza, los hijos menores de Melchor de Aguirre contra Baltasar Pérez Capote, vecino de Cabra, sobre agravios de cuentas. caja 10340, pieza 17.

36 Ibidem f. $290 \mathrm{v}$.

${ }^{37}$ Se trata de cláusulas comunes en los contratos en toda la España de la época con las que se trataba de prevenir que los maestros introdujeran cambios en las condiciones inicialmente pactadas para aumentar su margen de beneficio, o el incumplimiento de las condiciones del contrato. ARAMBURU-ZABALA HIGUERA, Miguel Ángel: Fraude y corrupción en la arquitectura del Siglo de Oro, Santander, Universidad de Cantabria, 2001, pp. 13-15. ${ }^{38}$ El remate o subasta era el método más frecuente utilizado en toda España durante en este período para obras de gran envergadura. ALONSO RUIZ, Begoña: El arte de la cantería. Los maestros trasmeranos de la Junta de Voto, Santander, Universidad de Cantabria, 1991, pp. 48-50.

${ }^{39}$ AHPCO Postura ...,op. cit., f. 290v. Pese a lo establecido en el contrato, la demolición de la estructura primitiva no fue completa, como demuestra el hecho de que tras la destrucción de la iglesia en julio de 1936, apareciese en las ruinas de la sacristía de la capilla «parte de un friso en yeso, árabe, que confirma las noticias de haber estado en ella la primitiva mezquita». Cfr: RAMOS ASENSIO, Antonio: «Informe que presenta don Antonio Ramos Asensio, miembro correspondiente de la Junta del Tesoro Artístico de Córdoba...[....]» en PALENCIA CEREZO, José María: «Destrucción y salvación del Patrimonio histórico-artístico en Baena durante la guerra civil», Boletín de la Real Academia de Córdoba de Ciencias, Bellas Letras y Nobles Artes, No. 140, (2001), p. 82.
} 
como Aguirre conocieron de primera mano. Con este sistema se obtendría una iluminación cenital muy barroca, que produciría un efecto parecido al conseguido en la capilla cordobesa, una «cascada de luz» que simula «una emanación de luz santa que baja hacia lo terrenal» cargada de simbolismo religioso ${ }^{40}$. Como es habitual en la España de la época, la media naranja no trasdosa al exterior, sino que se enmascaraba dentro de una «caja», en este caso ochavada, con un remate de piedra y una veleta en el tejado ${ }^{41}$. Se le adosaba sacristía propia, de planta rectangular y cubierta de colgadizo de madera.

\section{Imagen 4}

Hipótesis de planta de Santa María la Mayor de Baena y sus capillas laterales antes de 1936

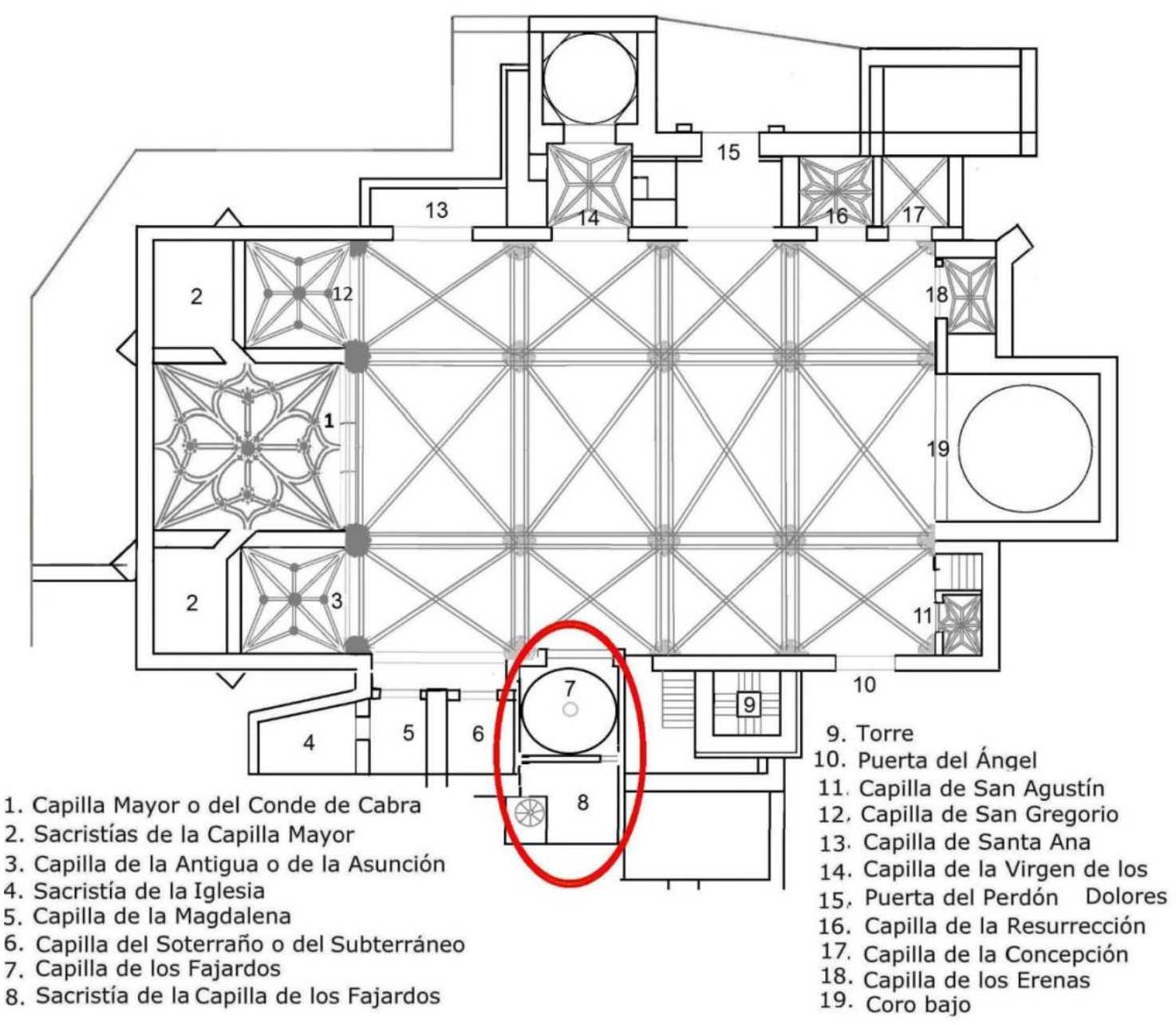

Fuente: Manuel Horcas Gálvez, inédito

40 RIVAS CARMONA, Jesús: «El arte franciscano .... », op. cit., p. 162.

${ }^{41}$ Ibídem ff. 291 r-292v. La media naranja se debía hacer de ladrillo recubiertos de yeso, en el que se practicarían labores de talla a modo de decoración. 
Se insiste en que todos los materiales utilizados sean «de buena calidad, bien labrado y lustrado». Para los elementos sustentantes se usaría «piedra franca de Luque de la de más firmeza que en ella se hallase», decorándose las pechinas con relieves escultóricos. En el resto del edificio se usarían ladrillo enlucido sobre el que iría una decoración de yeserías talladas. La portada de la capilla hacia el interior de la parroquia se haría con piedra ripia dura de Luque, y en ella iría el escudo de armas del fundador ${ }^{42}$.

Pero sin duda el aspecto más importante, por el que este proyecto destaca en el panorama artístico de la época, es la abundante decoración de jaspes polícromos de las canteras de la Subbética en paredes, suelos y retablo. Granados había empleado jaspes en encargos anteriores, pero nunca a esta escala ${ }^{43}$. El jaspe rojo de las canteras de Cabra o Luque sería el elemento predominante. Se usaría en el zócalo, el basamento, y en las gradas de la entrada de la capilla y «la peana del altar». También en el frontal del altar, aunque en este caso, con los perfiles dorados. En la solería ajedrezada se alternarían losas rojas y negras. Esta misma combinación cromática se usaría en la estructura del retablo, en el que irían algunos elementos decorativos tallados y dorados realizados en «madera de pino» o en «piedra ripia de buen grano» ${ }^{44}$.

Para el enterramiento de los patronos, y debido a las limitaciones de espacio, se prevé la construcción de una bóveda subterránea de arista hecha con ladrillos «del tamaño a que diere lugar la capacidad del hueco de dicha capilla», con unos "posos» para los ataúdes y unas escaleras para poder bajarlos con comodidad a las que se accedería por una abertura a ras del suelo, en la zona de ingreso a la capilla desde la nave de la iglesia, cerrada con una gran losa del mismo jaspe utilizado en la solería ${ }^{45}$. Se optaba así por una solución modesta, que prescinde de cenotafios o esculturas orantes del difunto como las que hay en su precedente cordobés, la capilla Salizanes.

El 4 de abril del mismo año, se escrituraron en Córdoba algunas obras suplementarias para enriquecer la decoración del frontal del altar y para labrar una taza de aguamanil para la pared de la sacristía. En este caso Granados ofreció un período de garantía de diez años, durante los cuales se comprometía a pagar los «aderezos que tuviere ocasionados de mal obrado» $^{46}$.

\footnotetext{
42 Ídem.

${ }^{43}$ TAYLOR, René: «El Arquitecto José Granados de la Barrera», Cuadernos de Arte de la Universidad de Granada, 12 (1975), p. 9, y MORENO ROMERA, Bibiana: Artistas y artesanos del Barroco granadino: documentación y estudio histórico de los gremios, Granada, Universidad de Granada, 2001, pp. 255 y 262-264. Esta autora sugiere que el contacto con Bartolomé Zumbigo, maestro mayor de la catedral de Toledo y experto marmolista, fue decisivo para que Granados empezara a utilizar estos materiales en sus obras.

${ }_{44}$ AHPCO, Postura ...,op. cit., f. 293r. Por desgracia se remite a las trazas y no se dan detalles sobre el retablo.

${ }^{45}$ Ibídem, f. 293v.

46 Ibídem, f. 296r.
} 


\section{La intervención de Melchor de Aguirre}

En el momento de su muerte, en 1685, Granados ya había traspasado la obra a Melchor de Aguirre ${ }^{47}$, un artista que también llegó a ser maestro mayor de la catedral de Granada entre los años 1688 y $1697^{48}$. Aunque no menciona fechas, Aguirre declara tener cartas de Pedro Luis Valenzuela en las que se habla de dicho traspaso, y que ha recibido una señal de mil reales de Juan Galiano, «thesorero de las rentas del Excmo. señor duque de Sessa en la villa de Doña Mencia, por aberme zedido dicha obra dicho don Joseph Granados» ${ }^{49}$. Una vez hecho el traspaso, había «sacado y labrado mucha cantidad de piedras y jaspes en diferenttes canteras en virtud de dicho encargo» ${ }^{50}$. De este modo, el artífice principal de la capilla Salizanes, el modelo en el que se inspira la capilla baenense, se hizo cargo del proyecto.

\section{Imagen 5}

\section{Firma de Melchor de Aguirre en la adjudicación de la fábrica de la capilla de Nuestra Señora del Oratorio ante el escribano de Baena Juan Muñoz Cardero}

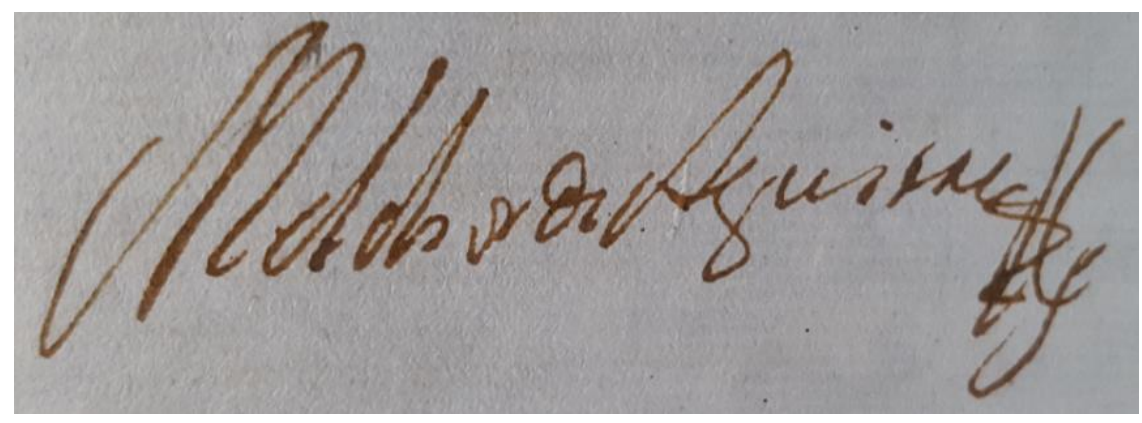

Fuente: AHPCO Postura ... op. cit., f. 304r.

\footnotetext{
${ }^{47}$ Aún está por determinar de forma concluyente qué tipo de relación profesional existió entre ambos. Lázaro Gila considera muy plausible que Aguirre fuera discípulo de Granados. GILA MEDINA, Lázaro: «La última etapa... », op. cit., p. 196. José Antonio Díaz lo da por hecho aunque no pueda probarse documentalmente, DÍAZ GÓMEZ, José Antonio: «Melchor de Aguirre, cantero y arquitecto: corpus de portadas y retablos», Anales de Historia del Arte, 27 (2017), pp. 143-145. Hay más ejemplos del apoyo y protección que Granados brindó a Aguirre. Por su mediación, estaba a cargo de las obras de una presa en el río Viudera, en los dominios del duque de Sessa en Rute y, cuando enfermó, Granados buscó un sustituto, Andrés García, que años más tarde trabajaría en las fortificaciones de Cádiz. Proposizión de Don Juan Núñez de Villavizenzzio en asumpto de la fábrica de Murallas. Archivo Histórico Municipal de Cádiz (AHMCA), L-10.053, 1697, f. $256 r$.

${ }^{48}$ Para una síntesis actualizada de la biografía de Aguirre cfr: SUÁREZ ARÉVALO, Jesús: «El legado de un arquitecto del Barroco. El testamento y el inventario de la biblioteca de Melchor de Aguirre» en: M.. A. RODRÍGUEZ MIRANDA et al. (coord.), El legado inequivoco de una época: Especial homenaje a Francisco Hurtado Izquierdo, Córdoba, Asociación para la Investigación de la Historia del Arte y el Patrimonio Cultural Hurtado Izquierdo, 2019, pp. 239-269. Disponible en: https://dialnet.unirioja.es/servlet/articulo?codigo $=7102044$ [fecha de Consulta 29 de Agosto de 2020].

${ }^{49}$ Como ya vimos, las obras se financiaban principalmente con los pagos de las deudas contraídas por el duque de Sessa.

${ }^{50}$ AHPCO, Postura..., op. cit., ff. 296v-297r.
} 
El traspaso no implicó en aquellos momentos la realización de un nuevo contrato. Este hecho se produciría más tarde, cuando se produjo la paralización de los trabajos en unos momentos y circunstancias que ignoramos. En 1692, los albaceas, liderados por Fernando José de Valenzuela, decidieron volver a contratar las obras a remate ${ }^{51}$. Se pregonaron durante 30 días en la plaza principal de Baena desde el 16 de octubre de 1692 hasta enero de 1693, sin que se presentara ningún otro interesado aparte de Aguirre, a quien finalmente se adjudicaron el 21 de marzo de 1693 con un plazo de ejecución de tres años, un presupuesto de sesenta mil reales y varias cláusulas de salvaguarda ${ }^{52}$.

Al igual que cuando se ocupó de la terminación de la portada de la catedral granadina, Melchor de Aguirre se «obliga de guardar y cumplir» las trazas de Granados ${ }^{53}$. Sin embargo, hace algunas modificaciones que hacen que su papel trascienda y no se limite a ser un maestro de obras que ejecuta las ideas de Granados, el arquitecto proyectista.

En el momento de su llegada únicamente está terminada la sacristía, de modo que tuvo un amplio margen de maniobra. En primer lugar, propuso una disminución del tamaño de la cripta funeraria, reduciéndola a «un bueco de dos baras de largo y tres cuartas de ancho y de peralte dos terzias, guarnecido [...] por todas partes de piedra jaspe con una losa de jaspe inscriptta y rotulada a faz del pabimento de la solería de jaspe» ${ }^{54}$.

Así mismo modifica la decoración de mármoles y jaspes, haciendo que sea aún más rica $^{55}$. Introdujo un elemento arquitectónico usado por él profusamente durante la etapa final de su carrera, el orden salomónico. De esta forma, convierte las columnas del retablo, que Granados había diseñado estriadas, en salomónicas. Además, se comprometía a dar «de grazia un pie de jaspe para el bufette de la sacristía ${ }^{56}$.

Al mismo tiempo que se llevaban a cabo estas labores en Baena, Aguirre tuvo un encargo de jaspes y solerías polícromas con destino a las paredes y suelos del camarín y antecamarín de la virgen de Guadalupe (Cáceres). Una visita al monasterio extremeño nos permite hacernos una idea sobre el aspecto que pudo tener la desaparecida capilla baenense ${ }^{57}$.

\footnotetext{
51 AHPCO, Postura ..., op. cit., ff. 298r.

${ }^{52}$ Ibídem ff. 299v-304r.

${ }^{53}$ GILA MEDINA, Lázaro: «La última etapa constructiva...»», op. cit., pp. 196-197.

${ }^{54}$ AHPCO, Postura ... op. cit., f. 296v.

55 «[...] los embutidos los tenía de executtar buscando diferentes jaspes de diversos colores para su mayor hornato, y en las quattro pechinas de la media naranja, thenía de poner quattro escudos de las armas del dicho Don Pedro Luis», Ibídem, f. 298r.

${ }^{56}$ Idem.

${ }^{57}$ SUÁREZ ARÉVALO, Jesús: «Jaspes cordobeses para la casa de la Virgen», Guadalupe - Revista del Real Monasterio de Guadalupe fundada en 1916, 866, (2019), pp. 12-15. Disponible en: https://drive.google.com/file/d/10iCFIwveCg3hPJg0A64tlvAfmFNWky5w/view . [fecha de Consulta 29 de agosto de 2020].
} 


\section{La culminación de las obras}

La destrucción de los archivos tanto de la parroquia como de la propia capilla en 1936 no nos permiten profundizar en las vicisitudes por las que pasó la fábrica de la capilla hasta su definitiva terminación en 1747. Puesto que la decoración de jaspes polícromos que caracterizaban a la capilla hasta su destrucción en julio de 1936 se corresponden con las que proyectaron Granados y Aguirre ${ }^{58}$, cuando éste último muere en 1697, la obra debía estar terminada o al menos muy avanzada, a falta únicamente de los elementos muebles, de los que, por desgracia, tenemos pocas referencias.

El testamento del fundador no menciona imágenes o pinturas destinadas a la capilla, pero en las escrituras de la fundación del patronato sí hay algunas alusiones genéricas a la donación de bienes muebles, como el frontal bordado para el altar, la alfombra o estera que deben ir delante del mismo, o una lámpara de plata y otros ornamentos litúrgicos no especificados $^{59}$. El dato más interesante es la mención a la donación de «los bestidos para las imágenes de nuestra Señora y mi padre San Joseph que an de estar en el dicho altar» ${ }^{60}$. El inventario post mortem del contenido del oratorio que había en la casa donde falleció, aunque bastante escueto en la descripción de las piezas, aporta más datos sobre la dotación de bienes muebles que el donante había destinado inicialmente a su fundación. Corresponden a un programa iconográfico de inspiración mariana, que refleja las devociones más queridas por el fundador y su esposa y al mismo tiempo guarda semejanzas con el de la ya mencionada capilla Salizanes ${ }^{61}$.

En el inventario se mencionan cinco cuadros (uno de san José con santa Ana y los cuatro restantes con efigies de santos: san Francisco de Paula, santa Anastasia, san Pedro y san Jerónimo), una lámina dorada y estofada de un eccehomo y dos esculturas (una virgen con «una cuna de plata y seis anillos de oro» y un san José) dentro de sendas «urnas de bidrio cristalino», además de relicarios, ropas litúrgicas y un completo ajuar litúrgico de piezas de plata entre las que los redactores del inventario destacan una lámpara y un Calvario de mesa en plata sobredorada ${ }^{62}$. No es posible saber si las imágenes de las que habla el inventario son

\footnotetext{
${ }^{58}$ RAMÍREZ DE LAS CASAS DEZA, Luis María: Corografía histórico-estadística ..., op. cit., p. 175.

${ }^{59}$ AHPCO, Fundación... op. cit., f. 77v.

${ }^{60}$ Ibídem, f. $81 \mathrm{v}$.

${ }^{61}$ NOVERO PLAZA, Raquel: Mundo y trasmundo de la muerte: los ámbitos y recintos funerarios del barroco español, Madrid, Fundación Universitaria Española, 2009, p. 266 y ROMERO TORRES, José Luis: «Pedro de Mena, Pedro Roldán y el concurso artístico de fray Alonso de Salizanes, obispo de Córdoba», Laboratorio de Arte, 24 (2012), pp. 262-263.

${ }^{62}$ Inventario, Aprecio y Almoneda..., op. cit., ff. 26r-27v. Todos los objetos de la capilla fueron entregados a los
} 
las mismas que tanto Casas Deza como Valverde Perales mencionan en sus descripciones del retablo de la capilla. Al parecer constaba de un grupo escultórico de la virgen con el niño, San José, San Joaquin y Santa Ana y debajo tres pinturas sobre cristal o cobre, la primera con la representación de la Sagrada Familia con San Joaquín y Santa Ana, y las otras dos con la Adoración de los Reyes Magos y de los Pastores respectivamente. Ninguna de estas pinturas aparece mencionada en el inventario, por lo que posiblemente fueran encargadas por los albaceas una vez acabada la construcción del edificio.

La descripción de Valverde Perales es la más extensa, y además habla de la decoración pictórica de la capilla, compuesta por 6 lienzos. Había dos lunetas de medio punto situados en la parte alta de las medianeras, entre las pechinas, que eran de temática mariana (la Asunción y la Concepción), y otros cuatro de santos (san Jerónimo, santa Marina, san Francisco de Paula y san Pedro Apóstol) de autoría, dimensiones, forma y ubicación no especificadas ${ }^{63}$, pero que se corresponden con los mencionados en el inventario ${ }^{64}$. También señala que la capilla, como era babitual en los recintos funerarios de este tipo, estaba cerrada por una verja de bronce en cuyo cerrojo habia una inscripción que aclaraba su autoría y su cronología ${ }^{65}$ : Antonio García me hizo en Lucena, año $1739^{66}$. Para Ramírez de Arellano, los adornos de cariátides de este cerrojo eran el elemento más destacable de la reja ${ }^{67}$.

Por su parte Casas Deza, aunque más breve, nos aporta el año de culminación de las obras, 1747 , y nos dice que sus muros estaban adornados por varios relicarios ${ }^{68}$, elementos que también aparecen mencionados en el inventario.

De la sacristía, la parte que primero se terminó, sólo sabemos que tenía un cuadro de la Sagrada Familia ${ }^{69}$. Al coincidir temáticamente con las esculturas de la capilla, podemos suponer que era la pintura que hacía las veces de retablo en esas dependencias. Además, había una pareja de retratos de cuerpo entero, de pie, y de tamaño natural de Pedro Luis Fajardo y su esposa, que según Ramírez de Arellano eran obras de Juan de Alfaro y Gámez, aunque el

albaceas el 17 de marzo de 1689, quedando en poder del presbítero Diego Patiño como depositario. Tras la muerte de este último, todo pasó a la casa de otro albacea, Gómez Fernández de Córdoba y Figueroa, conocida hoy como palacio de Viana, y cuando finalizaron las obras de la capilla, finalmente trasladado a Baena. Ibídem, ff 54v., 69r, 77r. y 80 r.

${ }^{63}$ VALVERDE Y PERALES, Francisco: Historia de la villa de Baena, Valladolid, Maxtor, 2007 (facsímil de la edición de Toledo, Imprenta y Librería de la Viuda e Hijos de J. Peláez, 1903), p. 299.

${ }^{64}$ Probablemente santa Anastasia fue erróneamente identificada con santa Marina.

${ }^{65}$ VALVERDE Y PERALES, Francisco: Historia de ..., op. cit., p. 300.

${ }^{66}$ Hizo además la reja del santuario de Nuestra Señora de Araceli en la propia Lucena, fechada por una inscripción en la misma reja en 1746; y las rejas de bronce dorado que cierran la entrada del coro de la catedral de Córdoba en 1759, AGUILAR PRIEGO, Rafael: «Bosquejo histórico de la ejecución de la sillería del coro de la catedral de Córdoba», Boletín de la Real Academia de Córdoba, 56 (1946), p. 61.

${ }^{67}$ RAMÍREZ DE ARELLANO, Rafael: Inventario monumental y artístico de la provincia de Córdoba, Córdoba, Monte de Piedad y Caja de Ahorros de Córdoba, 1983, p. 401.

${ }^{68}$ RAMÍREZ DE LAS CASAS DEZA, Luis María: Corografía histórico-estadística ..., op. cit., p. 175

${ }^{69}$ Idem. 
retrato del fundador tenía algunos repintes $»^{70}$. Palencia Cerezo, aunque da por válida esta atribución da noticia de otros informes antiguos que la cuestionan ${ }^{71}$. En caso de que se pudiera confirmar, estaríamos ante otro punto de contacto con la capilla Salizanes, para cuya sacristía Alfaro pintó un retrato del prelado fundador ${ }^{72}$. Sin embargo, el hecho de que los retratos no aparezcan en el inventario parece descartar que fueran pintados directamente para Pedro Luis Valenzuela y sugiere que fueron encargados a posteriori por sus albaceas y por tanto no pudieron ser pintados por Alfaro, fallecido en 1680.

\section{A modo de epílogo}

La capilla de nuestra Señora del Oratorio o de los Fajardo es un espacio funerario poco estudiado hasta ahora debido a la coincidencia de varios factores.

En primer lugar, debido a su estilo barroco fue minusvalorado por los cronistas de finales del siglo XIX y principios del XX. Valverde Perales llegó a calificarlo «de aparatoso aspecto, pero de escaso mérito artístico-arqueológico» ${ }^{73}$. Para Amador de los Ríos era «pretenciosa y moderna» ${ }^{74}$.

En segundo lugar, su trágica destrucción en julio de 1936 junto a gran parte de la iglesia de la que formaba parte, la parroquia de Santa María la Mayor, agravada por la ausencia de testimonios gráficos, ha hecho que se pierda la memoria de su misma existencia.

La breve aproximación documental que hemos abordado en estas páginas nos permite reivindicarla como un hito destacado del barroco andaluz de finales del siglo XVII en el que trabajaron algunos de los mejores artistas que trabajaron con los mármoles y jaspes polícromos en la Andalucía de la época, José Granados de la Barrera y Melchor de Aguirre. Podemos caracterizarla como un interesante ejemplo de emulación de las capillas funerarias que erigieron algunos prelados españoles siguiendo la estela del barroco romano, y en concreto de la capilla de Nuestra Señora de la Concepción en la Catedral de Córdoba, obra también de Melchor de Aguirre.

\footnotetext{
${ }^{70}$ RAMÍREZ DE ARELLANO, Rafael: Inventario monumental... , op. cit. p. 1982.

71 PALENCIA CEREZO, José María: «Obras cordobesas de Juan de Alfaro y Gámez (1643-1680)», Goya: Revista de arte, 283-284 (2001), pp. 249-250 y PALENCIA CEREZO, José María: «Destrucción y salvación...», op. cit., p. 82. Se trata de un informe elaborado en 1937 por Antonio Ramos Asensio, miembro correspondiente de la Junta del Tesoro Artístico de Córdoba, donde se los considera obras anónimas de escuela madrileña.

72 PALENCIA CEREZO, José María: «Obras cordobesas... », op. cit., p. 248.

${ }^{73}$ VALVERDE Y PERALES, Francisco: Historia de la Villa..., op. cit., p. 299.

${ }^{74}$ AMADOR DE LOS DE LOS RÍOS Y VILLALTA, Rodrigo: «Recuerdos de Baena (Córdoba). La parroquia de Santa. María la Mayor», La Ilustración Española y Americana, XLVI, 48 (30 de diciembre, 1902), p. 398.
} 